\title{
Cytotoxicity of chlorhexidine digluconate to murine macrophages and its effect on hydrogen peroxide and nitric oxide induction
}

C. Bonacorsi ${ }^{1}$,

M.S.G. Raddi ${ }^{2}$ and I.Z. Carlos ${ }^{2}$
Correspondence

I.Z. Carlos

Departamento de Análises Clínicas

Faculdade de Ciências Farmacêuticas

Rua Expedicionários do Brasil, 1621

14801-902 Araraquara, SP

Brasil

Fax: +55-16-222-0073

E-mail: carlosiz@fcfar.unesp.br

Research supported by FAPESP (No. 00/04305-0) and PADC/FCF (No. 2000/4-I).

Received February 27, 2003 Accepted September 16, 2003

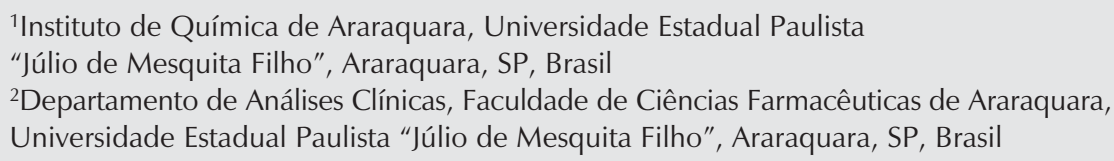

\section{Abstract}

Chlorhexidine, even at low concentrations, is toxic for a variety of eukaryotic cells; however, its effects on host immune cells are not well known. We evaluated in vitro chlorhexidine-induced cytotoxicity and its effects on reactive oxygen/nitrogen intermediate induction by murine peritoneal macrophages. Thioglycollate-induced cells were obtained from Swiss mice by peritoneal lavage with $5 \mathrm{ml}$ of $10 \mathrm{mM}$ phosphate-buffered saline, washed twice and resuspended $\left(10^{6}\right.$ cells/ $\mathrm{ml}$ ) in appropriate medium for each test. Cell preparations contained more than $95 \%$ macrophages. The cytotoxicity was determined by the 3-(4,5-dimethylthiazol-2-yl)-2,5-diphenyl-tetrazolium bromide assay and the presence of hydrogen peroxide $\left(\mathrm{H}_{2} \mathrm{O}_{2}\right)$ and nitric oxide (NO) by the horseradish peroxidase-dependent oxidation of phenol red and Griess reaction, respectively. The midpoint cytotoxicity values for 1and 24-h exposures were $61.12 \pm 2.46$ and $21.22 \pm 2.44 \mu \mathrm{g} / \mathrm{ml}$, respectively. Chlorhexidine did not induce synthesis or liberation of reactive oxygen/nitrogen intermediates. When macrophages were treated with various sub-toxic doses for $1 \mathrm{~h}(1,5,10$, and $20 \mu \mathrm{g} / \mathrm{ml})$ and $24 \mathrm{~h}(0.5,1$, and $5 \mu \mathrm{g} / \mathrm{ml})$ and stimulated with $200 \mathrm{nM}$ phorbol myristate acetate (PMA) solution, the $\mathrm{H}_{2} \mathrm{O}_{2}$ production was not altered; however, the NO production induced by $10 \mu \mathrm{g} / \mathrm{ml}$ lipopolysaccharide (LPS) solution varied from $14.47 \pm 1.46$ to $22.35 \pm 1.94 \mu \mathrm{mol} /$ 1 and $13.50 \pm 1.42$ to $20.44 \pm 1.40 \mu \mathrm{mol} / \mathrm{l}(\mathrm{N}=5)$. The results showed that chlorhexidine has no immunostimulating activity and sub-toxic concentrations did not affect the response of macrophages to the soluble stimulus PMA but can interfere with the receptor-dependent stimulus LPS.

\section{Introduction}

Chlorhexidine is an antibacterial agent widely used for skin disinfection, preoperative whole-body disinfection, and prevention and treatment of oral disease because of
Key words

- Chlorhexidine

- Cytotoxicity

- Macrophages

- Nitric oxide

- Hydrogen peroxide

.................... its broad-spectrum efficacy, retention by the skin and mucosa, and low risk of allergic complications (1). In recent years, vaginal washing with this compound before or during delivery has been suggested to prevent the development of both maternal and neo- 
natal infections (2-4). Studies have shown that small amounts of chlorhexidine are absorbed through the skin and vaginal mucosa $(3,5)$ and that, even at low concentrations, this compound has toxic effects on a variety of eukaryotic cells (6). However, these effects on host immune cells are not well known.

Macrophages are widely distributed in different tissues and play an essential role in the development of the specific and nonspecific immune response. These cells can be activated by a variety of stimuli such as bacterial components, cytokines and chemicals. Once activated, macrophages produce and release numerous secretory products including several cytokines, inorganic reactive radicals, reactive oxygen intermediates (ROI) and reactive nitrogen intermediates (RNI), all having biological activity (7). Hydrogen peroxide $\left(\mathrm{H}_{2} \mathrm{O}_{2}\right)$ and nitric oxide $(\mathrm{NO})$ are important in cell signaling and are effector molecules for the microbicidal and cytotoxic response of macrophages after stimulation (8). If ROI and RNI may be considered as beneficial intermediates (with respect to their microbicidal and tumoricidal activities), they can also become destructive for the host tissue under certain conditions (9). There is insufficient information about the effect of chlorhexidine on macrophage function.

The purposes of the present study were to determine in vitro the cytotoxicity of chlorhexidine digluconate to murine peritoneal macrophages and investigate whether this compound induces the production of ROI and RNI as well as to determine if chlorhexidine treatment affects macrophage functions in the presence of stimulation with phorbol myristate acetate (PMA) and lipopolysaccharide (LPS).

\section{Material and Methods}

\section{Chemicals}

Chlorhexidine digluconate was obtained from Henri Pharma Produtos Farmacêuticos (São Paulo, SP, Brazil). Dextrose, horseradish peroxidase (HRP), LPS, penicillin, phenol red, PMA, RPMI-1640 and streptomycin were purchased from Sigma (St. Louis, MO, USA). Brewer thioglycollate medium was purchased from Difco (Detroit, MI, USA). Fetal bovine serum (FBS) was obtained from Cultilab (Campinas, SP, Brazil). 2-Mercaptoethanol, sodium hydroxide and sodium chloride were purchased from Merck (Darmstadt, Germany).

\section{Animals}

Swiss mice (6-8 weeks old, weighing 18 to $25 \mathrm{~g}$ ), supplied by the Faculdade de Ciências Farmacêuticas, Universidade Estadual Paulista, Araraquara, SP, Brazil, were maintained in a polycarbonate box (at $23 \pm 1{ }^{\circ} \mathrm{C}$, $55 \pm 5 \%$ humidity, $10-18$ circulations/h and a 12-h light/dark cycle), with water and food available ad libitum.

\section{Peritoneal macrophages}

Resident and thioglycollate-elicited peritoneal exudate cells were obtained from mice following intraperitoneal injection of $3 \mathrm{ml}$ thioglycollate medium $(3.0 \mathrm{~g} / 100 \mathrm{ml})$ and lavage of the peritoneal cavity with $5 \mathrm{ml}$ of $10 \mathrm{mM}$ phosphate-buffered saline (PBS), $\mathrm{pH}$ 7.2, 3-4 days later. The proportion of macrophages in the peritoneal exudate was determined by cell staining with MayGrünwald-Giemsa. Cell preparations contained more than $95 \%$ macrophages. The cells were washed twice with PBS and resuspended in appropriate medium for each test.

\section{Cytotoxicity assay}

Macrophages $\left(2 \times 10^{6}\right.$ cells $\left./ \mathrm{ml}\right)$ were suspended in RPMI-1640 containing 5\% heatinactivated FBS, $100 \mathrm{IU} / \mathrm{ml}$ penicillin, 100 $\mu \mathrm{g} / \mathrm{ml}$ streptomycin and $50 \mathrm{mM} 2$-mercaptoethanol. The suspension $(100 \mu 1)$ was added 
to each well of a 96-well tissue culture plate and the cells were incubated at $37^{\circ} \mathrm{C}$ in a humidified atmosphere containing $5 \% \mathrm{CO}_{2}$. After $1 \mathrm{~h}$, the wells were washed and adhering cells exposed to different concentrations of chlorhexidine for 1 and $24 \mathrm{~h}$. The test was accompanied by a viability positive control (medium + cells) and negative control (medium + chlorhexidine). Finally, the 3-(4,5dimethylthiazol-2-yl)-2,5-diphenyl-tetrazolium bromide (MTT) assay (10) was performed and the absorbance at $540 \mathrm{~nm}$ determined with a microplate reader (Spectra III Classic, Tecan Austria Ges.m.b.H, Salzburg, Austria.

\section{Hydrogen peroxide}

$\mathrm{H}_{2} \mathrm{O}_{2}$ was measured by the HRP-dependent oxidation of phenol red (11). Macrophages $\left(2 \times 10^{6}\right.$ cells $\left./ \mathrm{ml}\right)$ were suspended in $10 \mathrm{mM}$ potassium phosphate buffer containing $140 \mathrm{mM} \mathrm{NaCl}, 5.5 \mathrm{mM}$ dextrose, 0.56 $\mathrm{mM}$ phenol red and $0.01 \mathrm{mg} / \mathrm{ml} \mathrm{HRP,} \mathrm{pH}$ 7.4. Briefly, $100 \mu \mathrm{l}$ of this suspension was added to each well of a 96-well tissue culture plate and exposed to different concentrations of chlorhexidine for $1 \mathrm{~h}$ (time for the $\mathrm{H}_{2} \mathrm{O}_{2}$ assay) at $37^{\circ} \mathrm{C}$ in a $5 \% \mathrm{CO}_{2}$ atmosphere. The reaction was stopped by the addition of $10 \mu \mathrm{l}$ of $1 \mathrm{~N} \mathrm{NaOH}$ and the absorbances were read at $620 \mathrm{~nm}$. The results are reported as $\mathrm{nmol} / \mathrm{ml}$ calculated from a hydrogen peroxide standard curve. The test was also performed with macrophages previously treated with sub-toxic concentrations of chlorhexidine for 1 and $24 \mathrm{~h}$, washed twice with $10 \mathrm{mM}$ potassium phosphate buffer and stimulated with PMA. The experiment was accompanied by a positive control (medium + cells +200 nM PMA solution) and negative control (medium + cells).

\section{Nitric oxide}

NO synthesis was determined by measuring the accumulation of nitrite $\left(\mathrm{NO}_{2}^{-}\right)$, a stable metabolite of NO, in culture supernatants using the Griess reaction (12). Macrophages at $5 \times 10^{6}$ cells $/ \mathrm{ml}$ in RPMI-1640 containing 5\% heat-inactivated FBS, 100 $\mathrm{IU} / \mathrm{ml}$ penicillin, $100 \mu \mathrm{g} / \mathrm{ml}$ streptomycin and $50 \mathrm{mM}$ 2-mercaptoethanol were added to each well of a 96-well cell culture plate and exposed to different concentrations of chlorhexidine for $24 \mathrm{~h}$ (time for the $\mathrm{NO}$ assay) at $37^{\circ} \mathrm{C}$ in a $5 \% \mathrm{CO}_{2}$ atmosphere. After incubation, 50- $\mu 1$ aliquots of culture supernatant were mixed with an equal volume of Griess reagent $(1 \% \mathrm{w} / \mathrm{v}$ sulfanilamide, $0.1 \% \mathrm{w} / \mathrm{v}$ naphthylethylenediamine and $3 \% \mathrm{H}_{3} \mathrm{PO}_{4}$ ), and incubated at room temperature for $10 \mathrm{~min}$. Absorbance at $540 \mathrm{~nm}$ was measured using a microplate reader. $\mathrm{NO}_{2}{ }^{-}$concentration $(\mu \mathrm{mol} / \mathrm{l})$ was calculated from an $\mathrm{NaNO}_{2}$ standard curve. The test was also performed with macrophages previously treated with sub-toxic concentrations of chlorhexidine for 1 and $24 \mathrm{~h}$, washed twice with RPMI-1640 and stimulated with LPS. Each experiment was accompanied by a positive control (medium + cells $+10 \mu \mathrm{g} / \mathrm{ml}$ LPS solution) and a negative control (medium + cells).

\section{Statistical analysis}

The midpoint cytotoxicity value, the concentration of chemical agent needed to reduce the spectrophotometric absorbance to $50 \%$, was determined by linear regression analysis with $95 \%$ confidence limits. $\mathrm{H}_{2} \mathrm{O}_{2}$ and $\mathrm{NO}$ concentrations are reported as means \pm SD. Statistical difference between groups was determined by one-way analysis of variance (ANOVA; $\mathrm{P}<0.05$ ). All experiments were carried out in triplicate and repeated at least three times.

\section{Results}

\section{Effect of chlorhexidine on cell viability}

Concentration-response cytotoxicity 
Figure 1. Effect of chlorhexidine on the viability of peritoneal macrophages after $1 \mathrm{~h}(\mathrm{~A})$ and $24 \mathrm{~h}$ (B). Each point and bar represents the mean \pm SD for at least three independent experiments carried out in triplicate. ${ }^{*} \mathrm{P}<0.05$ compared to control (ANOVA). curves for 1- and 24-h exposures of macrophages to chlorhexidine are shown in Figure 1. Initial toxicity, i.e., a statistically significant reduction in the viability of chlorhexidine-exposed cells relative to unexposed controls, occurred at $>20 \mu \mathrm{g} / \mathrm{ml}$ chlorhexidine with 1-h exposure and at $>5 \mu \mathrm{g} / \mathrm{ml}$ with 24-h exposure. Concentrations below these

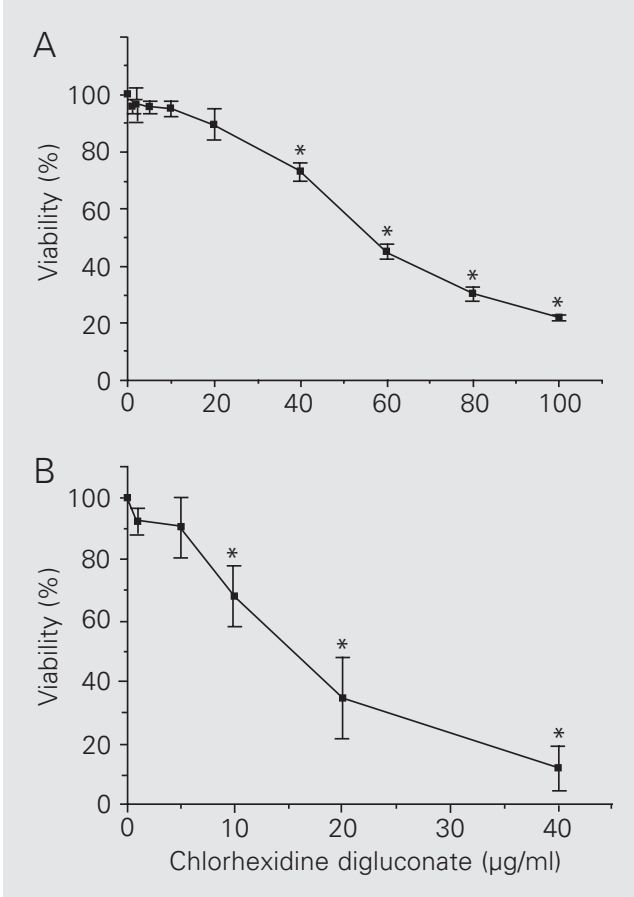

Table 1. $\mathrm{H}_{2} \mathrm{O}_{2}$ and $\mathrm{NO}$ production by peritoneal macrophages stimulated with chlorhexidine.

\begin{tabular}{lcc}
\hline $\begin{array}{l}\text { Chlorhexidine } \\
(\mu \mathrm{g} / \mathrm{ml})\end{array}$ & $\begin{array}{c}\text { After } 1 \mathrm{~h} \\
\mathrm{H}_{2} \mathrm{O}_{2}(\mathrm{nmol} / \mathrm{ml})\end{array}$ & $\begin{array}{c}\text { After } 24 \mathrm{~h} \\
\mathrm{NO}_{2}{ }^{-}(\mu \mathrm{mol} / \mathrm{l})\end{array}$ \\
\hline Control & $0 \pm 0.64$ & $1.21 \pm 0.25$ \\
1 & $0.13 \pm 0.70$ & $0.61 \pm 0.80$ \\
10 & $0.20 \pm 0.90$ & $0.57 \pm 0.23$ \\
60 & $0.21 \pm 0.55$ & $0.43 \pm 0.11$ \\
100 & $0.81 \pm 0.82$ & $0.52 \pm 0.15$ \\
PMA & $14.40 \pm 1.81^{*}$ & - \\
LPS & - & $37.50 \pm 2.85^{*}$
\end{tabular}

Macrophages were exposed to chlorhexidine for 1 and $24 \mathrm{~h}$. Data are reported as the mean \pm SD for at least three independent experiments carried out in triplicate. LPS = lipopolysaccharide, PMA $=$ phorbol myristate acetate .

${ }^{*} \mathrm{P}<0.05$ compared to control (ANOVA). were designated as sub-toxic. The midpoint cytotoxicity values were $61.12 \pm 2.46$ and $21.22 \pm 2.44 \mu \mathrm{g} / \mathrm{ml}$.

\section{Effect of chlorhexidine on $\mathrm{H}_{2} \mathrm{O}_{2}$ and NO induction}

To evaluate the ability of chlorhexidine to induce the production and liberation of ROI and RNI, murine macrophages were exposed to various concentrations of the test substance for 1 and $24 \mathrm{~h}$ (time for the $\mathrm{H}_{2} \mathrm{O}_{2}$ and $\mathrm{NO}$ assay, respectively). At none of the concentrations tested did chlorhexidine induce the production of $\mathrm{H}_{2} \mathrm{O}_{2}$ or $\mathrm{NO}$ by macrophages (Table 1).

\section{Production of $\mathrm{H}_{2} \mathrm{O}_{2}$ and $\mathrm{NO}$ by chlorhexidine-exposed macrophages}

To determine the effect of chlorhexidine on $\mathrm{H}_{2} \mathrm{O}_{2}$ and $\mathrm{NO}$ production by macrophages, these cells were treated with sub-toxic concentrations of chlorhexidine for 1 and $24 \mathrm{~h}$ and stimulated with both PMA and LPS. Table 2 shows that the $\mathrm{H}_{2} \mathrm{O}_{2}$ production was not altered in macrophages exposed to chlorhexidine for 1 and $24 \mathrm{~h}$ but the NO production induced by LPS was reduced when macrophages were exposed to sub-toxic doses of chlorhexidine (Figure 2).

\section{Discussion}

Macrophages have been used for immunocytotoxicity testing because they permit the measurement of the cytotoxic response directly in the cell culture and because of their ability to maintain immunological functions in the presence of many different chemical agents (13). The cytotoxicity of chlorhexidine has been assayed using cell lines or primary cultures of mammalian cells (6); however, there is no specific information on the toxicity of this substance to immune cells. In the present study, we demonstrated that macrophages are as sensitive to the toxic 
effects of chlorhexidine as other cell types and that the cytotoxic potential of the substance is dependent on the concentration and time of exposure (14). It is important to note that chlorhexidine digluconate is toxic to macrophages in vitro at concentrations 100 times below those used in clinical practice, usually $0.2-0.5 \%$ (15).

In response to antigens or inflammatory signals generated at sites of tissue injury, macrophages undergo a process of cellular "activation" which is associated with morphological, functional, and biochemical changes in the cells. One prominent characteristic of activated macrophages is their increased capacity to release pro-inflammatory and cytotoxic mediators, which aid in antigen destruction (16).

The present data show that chlorhexidine does not induce the production of ROI/RNI by macrophages. When macrophages were treated with chlorhexidine (sub-toxic concentrations) for 1 and $24 \mathrm{~h}$ and stimulated with PMA there was no alteration in $\mathrm{H}_{2} \mathrm{O}_{2}$ production. However, NO production induced by LPS was decreased in macrophages previously treated with sub-toxic doses of this substance. These observations are probably relevant to the mechanism underlying chlorhexidine-induced cytotoxicity.

Chlorhexidine may adversely affect the eukaryotic plasma membrane by nonspecific electrostatic binding to negative moieties (protein and phospholipid components), causing alteration in the structure of the cell membrane and in the osmotic equilibrium of the cell $(6,14)$. PMA is a soluble stimulus that acts directly on protein kinase $\mathrm{C}$ (present in cytoplasm) activating the production of the superoxide anion, which is subsequently converted to $\mathrm{H}_{2} \mathrm{O}_{2}$ (17). PMA-induced stimulation can be mediated by specific receptors, and also via insertion into the membrane due to its hydrophobic nature (18). Probably, chlorhexidine does not prevent the entry of PMA into the cell, since this substance also acts by a receptor-independ- ent mechanism.

Several types of receptors have been reported to be present on the macrophage surface. The inhibitory effect of several chemicals (ligands) on NO production induced by LPS would appear to be derived from the inhibition of LPS binding to the receptor through ligand-LPS complex formation or ligands may compete for LPS receptor (19). However, in our study, the reduction in the

Table 2. $\mathrm{H}_{2} \mathrm{O}_{2}$ production by macrophages treated with chlorhexidine for 1 and $24 \mathrm{~h}$ and stimulated with PMA.

\begin{tabular}{lcc}
\hline $\begin{array}{l}\text { Chlorhexidine } \\
(\mu \mathrm{g} / \mathrm{ml})\end{array}$ & $\begin{array}{c}1 \mathrm{~h} \\
(\mathrm{nmol} / \mathrm{ml})\end{array}$ & $\begin{array}{c}24 \mathrm{~h} \\
(\mathrm{nmol} / \mathrm{ml})\end{array}$ \\
\hline Control & $7.73 \pm 0.84$ & $5.30 \pm 0.34$ \\
0.5 & - & $5.07 \pm 0.65$ \\
1.0 & $6.75 \pm 0.70$ & $5.55 \pm 0.57$ \\
5 & $6.90 \pm 0.73$ & $5.32 \pm 0.37$ \\
10 & $7.91 \pm 1.20$ & - \\
20 & $6.96 \pm 1.00$ & - \\
\hline
\end{tabular}

Data are reported as the mean \pm SD for at least three independent experiments carried out in triplicate.

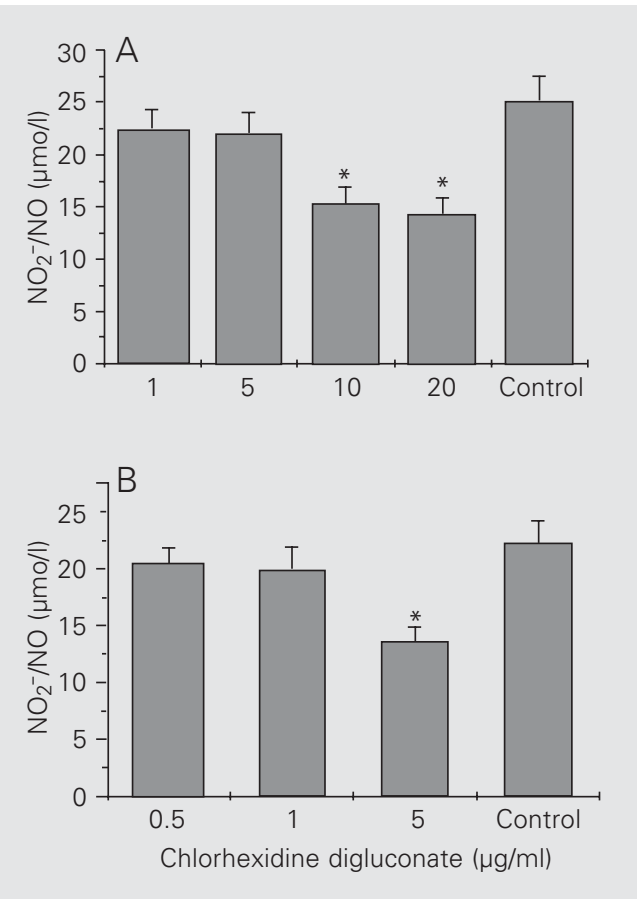

Figure 2. NO production by macrophages treated with chlorhexidine for $1 \mathrm{~h}(\mathrm{~A})$ and $24 \mathrm{~h}(\mathrm{~B})$ and stimulated with LPS. Data are reported as the mean \pm SD for at least three independent experiments carried out in triplicate. ${ }^{*} \mathrm{P}<0.05$ compared to control (ANOVA). 
NO production by chlorhexidine-treated macrophages is likely the result of the action of this substance on plasma membrane. Chlorhexidine may interact or damage membrane receptors interfering in the binding receptorLPS.

The products of the oxidative burst are used to kill phagocytic pathogens and also for the extracellular destruction of other cells. Based on the results obtained here we conclude that chlorhexidine does not produce an immunostimulatory effect. However, this substance may have an immunosuppressive effect on exposed macrophages which is related to receptor-dependent particulate stimuli.

\section{References}

1. McDonnell G \& Russell AD (1999). Antiseptics and disinfectants: activity, action and resistance. Clinical Microbiology Reviews, 12: 147-179.

2. Facchinetti F, Piccinini F, Mordini B \& Volpe A (2002). Chlorhexidine vaginal flushing versus systemic ampicillin in the prevention of vertical transmission of neonatal group B streptococcus, at term. Journal of Maternal Fetal Medicine, 11: 84-88.

3. Nilsson G, Larsson L, Christensen KK, Christensen P \& Dykes AK (1989). Chlorhexidine for prevention of neonatal colonization with group B streptococci. V. Chlorhexidine concentrations in blood following vaginal washing during delivery. European Journal of Obstetrics, Gynecology, and Reproductive Biology, 31: 221-226.

4. Stray-Pedersen B, Bergan T, Hafstad A, Normann E, Grogaard J \& Vangdal M (1999). Vaginal disinfection with chlorhexidine during childbirth. International Journal of Antimicrobial Agents, 12: 245251.

5. Lafforgue C, Carret L, Falson F, Reverdy ME \& Freney J (1997). Percutaneous absorption of a chlorhexidine digluconate solution. International Journal of Pharmaceutics, 147: 243-246.

6. Hidalgo E \& Dominguez C (2001). Mechanisms underlying chlorhexidine-induced cytotoxicity. Toxicology in Vitro, 15: 271-276.

7. Forman HJ \& Torres M (2001). Redox signaling in macrophages. Molecular Aspects of Medicine, 22: 189-216.

8. Kayser O, Kolodziej H \& Kiderlen AF (2000). Immunomodulatory principles of Pelargonium sidoides. Phytotheraphy Research, 15: 122-126.

9. McBride AG, Borutaité V \& Brown GC (1999). Superoxide dismutase and hydrogen peroxide cause rapid nitric oxide breakdown, peroxynitrite production and subsequent cell death. Biochimica et Biophysica Acta, 1454: 275-288.

10. Mosmann T (1983). Rapid colorimetric assay for cellular growth and survival: application to proliferation and cytotoxicity assay. Journal of Immunological Methods, 65: 55-63.

11. Pick E \& Mizel D (1981). Rapid microassays for the measurement of superoxide and hydrogen peroxide production by macrophages in culture using an automatic enzyme immunoassay reader. Journal of Immunological Methods, 46: 211-226.

12. Green LC, Wagner DA, Glogorwki J, Skipper PL, Wisnok JS \& Tannenbowm SR (1982). Analysis of nitrate, nitrite and $\left({ }^{15} \mathrm{~N}\right)$ nitrate in biological fluids. Analytical Biochemistry, 126: 131-138.

13. Barile FA, Dierickx PJ \& Kristen U (1994). In vitro cytotoxicy testing for prediction of acute human toxicity. Cell Biology and Toxicology, 10: 155-162.

14. Babich H, Wurzburger BJ, Rubin YL, Sinensky MC \& Blau L (1995). An in vitro study on the cytotoxicity of chlorhexidine digluconate to human gingival cells. Cell Biology and Toxicology, 11: 79-88.

15. Adriaanse AH (1995). Prevention of neonatal septicemia due to group B streptococci. Baillieres Clinical Obstetrics and Gynaecology, 9: 545-552.

16. Laskin DL \& Laskin JD (2001). Role of macrophages and inflammatory mediators in chemically induced toxicity. Toxicology, 160: 111118.

17. Komatsu H, Tsukimori K, Hata K, Satoh S \& Nakano H (2001). The characterization of superoxide production of human neonatal neutrophil. Early Human Development, 65: 11-19.

18. Bender JG, McPhail LC \& van Epps DE (1983). Exposure of human neutrophils to chemotactic factors potentiates activation of the respiratory burst enzyme. Journal of Immunology, 130: 2316-2323.

19. Matsudo R, Amaraki Y, Arima H \& Tsuchiya S (1997). Scavenger receptors may regulate nitric oxide production from macrophages stimulated by LPS. Biochemical and Biophysical Research Communications, 237: 601-605. 